Blasted Literature 
Edinburgh Critical Studies in Victorian Culture

Series Editor: Julian Wolfreys

Volumes available in the series:

In Lady Audley's Shadow: Mary Elizabeth Braddon and Victorian Literary Genres

Saverio Tomaiuolo

$9780748641154 \quad$ Hbk

Blasted Literature: Victorian Political Fiction and the Shock of Modernism

Deaglán Ó Donghaile

$9780748640676 \quad$ Hbk

William Morris and the Idea of Community: Romance, History and Propaganda, 1880-1914

Anna Vaninskaya

9780748641499 Hbk 


\section{Blasted Literature}

Victorian Political Fiction and the Shock of Modernism

Deaglán Ó Donghaile 
(C) Deaglán Ó Donghaile, 2011

Edinburgh University Press Ltd

22 George Square, Edinburgh

www.euppublishing.com

Typeset in $10.5 / 13$ pt Sabon

by Servis Filmsetting Ltd, Stockport, Cheshire, and printed and bound in Great Britain by

CPI Antony Rowe, Chippenham and Eastbourne

A CIP record for this book is available from the British Library

ISBN 9780748640676 (hardback)

The right of Deaglán Ó Donghaile

to be identified as author of this work

has been asserted in accordance with

the Copyright, Designs and Patents Act 1988. 